\title{
Health problems due to dental practice at the public service of Campina Grande / PB / Brazil
}

\section{Problemas de saúde em cirurgiões-dentistas do serviço público de Campina Grande/PB/Brazil}

\author{
Maria Suênia Pereira da SILVA \\ MS in Dentistry - State University of Paraiba - Campina Grande - Paraiba - Brazil. \\ Maria Helena Chaves de Vasconcelos CATÃO \\ $\mathrm{PhD}$ - Professor - Graduate Program in Dentistry - Department of Dentistry - State University of \\ Paraiba - Campina Grande - Paraiba - Brazil.
}

\section{Joaquina de Araújo AMORIM}

Deborah Yara Sarmento de Abrantes PEREIRA

DDS - Campina Grande - Paraiba - Brazil.

\begin{abstract}
ABSTR ACT
The aim of this study was to identify health problems resulted from dental practice. The sample consisted of 32 dentists. A questionnaire comprising mainly objective questions was used. Data were analyzed descriptively and presented in tables. Most of the respondents were females (75\%) and the predominant age range was 26-35 years (40.6\%). Fifty-three point one percent of dentists had already suffered cutting and punching accidents during their activity. Considering the occupational diseases, $62.5 \%$ of participants had in the past or still present them, while the rest $37.5 \%$ of the participants have never had this type of disease. The most prevalent clinical complaint was muscle pain in lumbar region (65\%), followed by pain in the spinal column (10\%). Tendinitis $(60 \%)$, varicose veins $(40 \%)$ and presbyopia $(40 \%)$ were the most prevalent diseases occasioned by the dental practice, according to the dentists. Therefore, in this study, most of the dentists working at the public health service in the city of Campina Grande (PB, Brazil) had undergone cutting and punching accidents, and most of them had or still present some occupational disease.
\end{abstract}

\section{K EYWORDS}

Occupational risks; cumulative trauma disorders; dentistry.

\section{INTRODUCT ION}

The postmodern society is increasingly more vulnerable to the so-called occupational diseases. The excess of consecutive working hours, the pressure for best results in short periods of time, and the execution of repetitive tasks are among the etiologic factors of serious health problems.

There is a group of diseases generally called Repetitive Strain Injury (RSI), in which people show signs and symptoms of inflammation of muscles, tendons and nerves of the upper body, scapular belt and neck, among others. This lesion type has drawn attention not only by its increasing incidence, but also by the existing evidences of its association with working rates [1].
The occupational diseases, which both dentists and other health professionals are exposed to, have been divided into two groups: 1) work accidents, characterized by lesion development in periods of time close to the activity of the noxious agents; 2) occupational diseases, characterized by the disease installation after long periods of time from the activity of noxious agents [2].

The occupational diseases seem to affect dentists even before their graduation. A study conducted by Presta et al. [3], with 60 senior undergraduate students from São Paulo State University (short Unesp) and 41 senior undergraduate students from São Paulo University (short Unip), found that most of the students of both schools felt or had already felt pain related to Dentistry practice, with pain in 
the back, neck and hands being the most frequent complaints. Similar results were observed in a study conducted by Díaz-Caballero et al. (2010) [4], who evaluated through a structured questionnaire, the ergonomic factors causing muscle pain in Dentistry undergraduate students. In relation to occupational accidents, $45 \%$ of the undergraduate students from UNESP and $17.1 \%$ of those from UNIP) reported its occurrence, with the most prevalence being cutting and punching accidents.

A study investigated bilaterally the electromyographic behavior and the referred fatigue point on deltoid (medial portion) and trapezius muscles (descending and transversal portions) in 40 female dental undergraduate students. The students had a mean age of 21 years-old and were evaluated according to their working specialties and divided into four groups: 1 - Periodontics, 2 - Surgery, 3 - General Dentistry and 4 - auxiliary team. The authors concluded that dental work performed by long daily periods resulted in the fatigue and pain of scapular belt and cervical muscles, regardless the type of clinical specialty [5].

According to Alpino [6], the extremely busy life pace and the lack of preventive measurements against occupational diseases have led certain dentists to interrupt their professional activity for a determined period, in order to be submitted to either corrective surgeries or palliative techniques, which ameliorate but do not definitively solve the problems. In other case scenarios, dentists have to quit working. The professional activity of dentists imposes the repeated use of the upper body and adjacent structures, with mechanical compression of the structures localized in the upper body. The adoption of incorrect postures by using excessive force and in most case scenarios, working under time pressure, is also frequent [7].

According to the literature, it is known that occupational diseases affecting dentists might present mechanical (WRMD/ RSI), physical, chemical, biological and also psychological origins [8]. The lack of information on specific working situations undergone by dentists often constitutes an obstacle for planning and implementing public actions and policies for the health of these professionals. The present study aimed to identify health problems related to the practice of dentistry in the public health service of the city of Campina Grande, Paraiba, Brazil.

\section{Material AND MEthods}

The study project was submitted to the Institutional Review Board of the State University of Paraiba and received the approval in December, 14, 2006, under protocol \#0306.0.133.00-606. The informed consent was obtained from the participants of the study. The sample comprised of 32 dentists working at Basic Health Units, at Family Health Basic Units and at Health Centers, distributed in the health districts of the urban area of the city of Campina Grande. The sample selection was casually and randomly performed, and represented $40 \%$ of the total number of dentists $(n=79)$.

A questionnaire comprising predominantly objective questions on the variables: gender, age range, occupational history, aspects related to occupational accidents and to occupational disease was applied. After the collection, data were descriptively displayed in tables. The study was performed in October/2009 by two researchers who visited the units during the operation hours to apply the questionnaire.

\section{RESULtS}

Most of the participants of the research were females (Table 1) within the age range from 26 to 35 years of age, followed by the age range from 46 to 55 years of age (Table 2).

TABle 1 - Gender of dentists working at the PUblic health SERVICE IN THE CITY OF CAMPINA GRANDE SELECTED FOR THE STUDY

\begin{tabular}{l|c|c}
\hline Gender & Frequency & Percentage \\
\hline Male & 8 & $25 \%$ \\
\hline Female & 24 & $75 \%$ \\
\hline Total & 32 & $100.0 \%$ \\
\hline
\end{tabular}

TABle 2 - Age RANGe of the dentists WORKING AT THE PUBLIC HEALTH SERVICE OF THE CITY OF Campina Grande who participated in the PRESENT STUDY

\begin{tabular}{l|c|c}
\hline Age range & Frequency & Percentage \\
\hline$<25$ years-old & 3 & $9.4 \%$ \\
\hline 26 to 35 years-old & 13 & $40.6 \%$ \\
\hline 36 to 45 years-old & 6 & $18.8 \%$ \\
\hline 46 to 55 years-old & 9 & $28.1 \%$ \\
\hline 56 to 65 years-old & 1 & $3.1 \%$ \\
\hline Total & 32 & $100.0 \%$ \\
\hline
\end{tabular}

Most of the interviewers (69\%) had been working for more than 20 years, while the rest $31 \%$ had been working from 4 to 7 years. 
Twenty-six dentists attended some specialty in Dentistry. Among the specialties, $25.6 \%$ of the participants were specialists in Collective Health. According to the data obtained on the weekly working hours of the public service, we found that $62.5 \%$ of the dentists worked 40 hours per week. The mean amount of patients treated per day, at the public service of Campina Grande, was between 14 to 20 patients, according to the responses interviewers working 40 hours weekly.

Concerning dentists working somewhere else, it was verified that $37.5 \%$ of dentists were included in this category.

In this study, all dentists affirmed that they used Personnel Protective Equipments (PPE). When they were asked on which PPEs they used, 93.7\% answered that they wore gloves, masks, goggles, bonnets and labcoats. Only $6.3 \%$, wore also ear protector. Concerning to cutting and punching accidents, 53.1\% of the dentists had already undergone this accident type during their occupation due to lack of attention $(59 \%)$ and hurried movements (41\%) (Table 3$)$.

TABLE 3 - OccurRence of CUTtING AND PUNCHING ACCIDENTS DURING DENTAL OCCUPATION AMONG DENTISTS WORKING AT THE PUBLIC HEALTH SERVICE OF THE CITY OF CAMPINA GRANDE AND PARTICIPATING IN THIS STUDY

\begin{tabular}{l|c|c}
\hline Cutting and punching accidents & Frequency & Percentage \\
\hline Yes & 17 & $53.1 \%$ \\
\hline No & 15 & $46.9 \%$ \\
\hline Total & 32 & $100.0 \%$ \\
\hline
\end{tabular}

In relation to occupational diseases, $62.5 \%$ of dentists reported clinical complaints. The most common clinical complaints were: pain in column, hearing impairment, pain in joints, and muscle fatigue (arm and neck). The muscle pain in lumbar region was present in $65 \%$ of these dentists, followed by pain in the spinal column (10\%). (Table 4).

Table 4 - Clinical complaints presented by THE DENTISTS WORKING AT THE PUBLIC HEALTH SERVICE OF THE CITY OF CAMPINA GRANDE AND PARTICIPATING IN THIS STUDY

\begin{tabular}{l|c|c}
\hline \multicolumn{1}{c|}{ Clinical complaints } & Frequency & Percentage \\
\hline Muscle pain in lumbar region & 13 & $65 \%$ \\
\hline Pain in the spinal column & 2 & $10 \%$ \\
\hline Muscle fatigue (arm and neck) & 1 & $5 \%$ \\
\hline Hearing impairment & 1 & $5 \%$ \\
\hline Pain in joints & 1 & $5 \%$ \\
\hline Not answered & 2 & $10 \%$ \\
\hline Total & 20 & $100 \%$ \\
\hline
\end{tabular}

Among the dentists, $46.8 \%$ presented in the past or was presenting diseases caused by their practice at the interview. Tendinitis (60\%), presbyopia (40\%), and cervical lordosis $(40 \%)$ were the most frequently observed (Table 5). It is important to note that ten dentists reported more than one of the diseases mentioned in the questionnaire.

Table 5 - Diseases caused by dental practice OF THE DENTISTS WORKING AT THE PUBLIC HEALTH SERVICE of the city of Campina Grande and PARTICIPATING IN THIS STUDY

\begin{tabular}{l|c|c}
\hline Diseases caused by dental practice & Frequency & Percentage \\
\hline Tendinitis & 9 & $60 \%$ \\
\hline Varicose veins & 6 & $40 \%$ \\
\hline Presbyopia & 6 & $40 \%$ \\
\hline Cervical lordosis & 3 & $20 \%$ \\
\hline Shoulder bursitis & 3 & $20 \%$ \\
\hline Severe stress & 2 & $13 \%$ \\
\hline Arthritis & 2 & $13 \%$ \\
\hline Herniated disc & 2 & $13 \%$ \\
\hline Insomnia & 2 & $13 \%$ \\
\hline Herpes simplex & 2 & $13 \%$ \\
\hline Carpal tunnel syndrome & 1 & $6.6 \%$ \\
\hline Scoliosis & 1 & $6.6 \%$ \\
\hline Contact Dermatitis & 1 & $6.6 \%$ \\
\hline Conjunctivitis & 1 & $6.6 \%$ \\
\hline
\end{tabular}

According to the results, RSI occurrence was higher among female dentists, with $54 \%$ of the interviewers showing some disease related to repetitive efforts or disturbs related to their practice. By analyzing the relationship between the occurrence of occupational disease and the amount of time of dental practice, it was verified that among dentists working over 20 years, the occurrence of diseases caused by dental practice was much higher (46.6\%), as already expected.

Concerning health monitoring, $73.3 \%$ of the participants were periodically submitted to examinations; the most common were ultrasonography $(8 \%)$ and serological tests $(8 \%)$. The audiometry was performed by only two of the 32 dentists interviewed. In relation to the frequency examinations were performed, $84 \%$ reported annually examination. Physical exercise practice is performed by $53 \%$ of the dentists.

Among the dentists interviewed, 53.1\% answered that offered working conditions were not proper for ensuring their health. To improve the working conditions, $15.6 \%$ pointed out that investments in 
infrastructure and reduction in number of treated patients would be the main requirements. The following affirmations comprised $12.5 \%$ of the answers: "To promote weekly physiotherapy activities to prevent occupational diseases of the dentists"; "Cabinets, air conditioner, capacity of the dentists of the Family Health Program"; Income increase for the oral health teams"; "Air conditioner"; "Professional training courses, educative material and better income (wage parity of the higher education professionals of the health team of the Family Health Program ), resulting in better health conditions"; "Air conditioner, trash can with lid and pedal"; "Income improvement and better valorization of the best professional, who really works for the sake of Dentistry" and "To allow that the dentist be updated".

\section{Discussion}

The Dentistry is an occupation that demands additionally to the intellectual capacity, great skill and physical effort, characteristics that certainly interfere negatively in the health of those who practice it and mainly in the health of the dentists. In a study conducted by Garbin et al. [9], with 76 dentists of the city of Araçatuba (São Paulo, Brazil), found that $34.0 \%$ of the interviewers affirmed to undergo some type of accident. Of these accidents, $84.6 \%$ were skin punctures and $30.8 \%$ were ocular lesions due to fragments.

Blank and Garcia [10], in a much larger study with 326 dentists also found that most of them (60.7\%) had suffered percutaneous lesion. In this present study, the results were similar to those verified in the aforementioned studies, as $53.1 \%$ of the dentists answered that they had undergone cutting and punching accidents during their practice. Rosa et al. [11] studied the behavior of dentists concerning the use of PPEs and concluded that $88.8 \%$ of the dentists did not wear the complete PPE. In this present study, the results were not different, once $93.7 \%$ of the dentists answered that they wore gloves, masks, goggles, bonnets and labcoats and only $6.3 \%$, wore ear protector additionally.

The incidence of disturbs of the musculoskeletal system, such as carpal tunnel syndrome is higher among women; however this affirmation, regardless of the labor factors, needs further studies to be proved. [1].

Cruz and Silveira [12] evaluated the dental work environment, based on the dentists' opinions and according to ergonomic criteria, regarding the importance given to the prevention of the occupational diseases, as well as the appearance of those during the practice. Of the 30 professionals interviewed, $90 \%$ already had occupational diseases, being 31to-40 year-old women working from 10 to 20 years were mostly affected by RSI and Work-Related Musculoskeletal Disorders (WRMD). This present study corroborates these results as females were more affected by RSI. In a study conducted with 91 dentists and 113 dental assistants who were interviewed and observed during their practice, $73.5 \%$ of these professionals complained about back pain and 54.4\% about neck pain [13]. Similar results were obtained by this present study, where $65 \%$ of the dentists interviewed reported muscle pain in lumbar region. These results corroborate a literature review study conducted by Leggat et. al. [14] in which they verified that back pain is the health problem most affecting dentists.

Santos Filho and Barreto [15] performed a study to verify the prevalence of musculoskeletal pain factors associated with its symptomatology in 358 dentists of the city of Belo Horizonte (Minas Gerais, Brazil). They observed that pain prevalence in upper body was $58 \%$, comprising mostly pain in the arm (22\%). In this present study, most of the dentists interviewed reported pain in the arm due to tendinitis associated with their practice.

According to Cruz and Silveira [12], 81\% of the dentists stated they had already presented RSI/ WRMD, reporting pain as the main symptom. Discomfort $(16.2 \%)$, feeling of tiredness in the arms $(60 \%)$, difficulty of movement $(75 \%)$ was also reported. In this present study, pain was also the main symptom, being pain in lumbar region shown in $65 \%$ of the dentists, followed by pain in spinal column $(10 \%)$.

A study conducted by Rosa et al. [11] detected that $15.4 \%$ of the dentists interviewed already had hepatitis. Unlikely, in this study, the interviewers affirmed never contracted hepatitis.

Gonçalves et al. [16] examined the probable effects of the occupational exposure of dentists to noise, their perception and knowledge towards the damage of the exposure to noise and its possibilities of prevention. In the aforementioned study, it was verified a prevalence of hearing alterations $(32.51 \%)$ in 163 dentists participating in the research. The occurrence of hearing alterations increased with increasing age and working years. Noise during working was perceived as medium (49.07\%); $96.9 \%$ knew the effects of noise and only $3.06 \%$ wore ear protectors. Similarly, in this present study, few 
participants $(6.3 \%)$ wore ear protector.

Since the influence of other factors, namely previous occupational history (occupations exerted by the dentist before working in Dentistry), familiar history (predisposition to develop cancer, allergies, etc.) and individual history (smoking, drinking, etc.), on the prevalence of the diseases mentioned by the dentists was not evaluated and knowing that these diseases may be aggravated by these factors, further studies including these influences should be conducted.

\section{Conclusion}

In this study, it was verified that most of the dentists participating in this research already suffered cutting and punching accidents during their practice and they had already suffered or were suffering any occupational disease or clinical complaint related to their practice.

Most of the dentist participating in this study mentioned muscle pain in lumbar region as clinical complaint and tendinitis as occupational disease.

\begin{abstract}
RESUMO
O objetivo deste estudo foi identificar os problemas de saúde considerados pelos Cirurgiões-Dentistas (CDs) como decorrentes da sua profissão. A coleta dos dados foi realizada em 2010 através de um questionário com perguntas objetivas respondido por 32 CDs. Os dados foram apresentados de forma descritiva e dispostos em tabelas. A maioria (75\%) dos CDs era do gênero feminino e a faixa etária predominante foi aquela de 26 a 35 anos (40.6\%). Entre os CDs, $53.1 \%$ já sofreram acidente perfurocortante durante o exercício da profissão. No caso das doenças profissionais, $62.5 \%$ dos CDs já tiveram ou tem e $37.5 \%$ não apresentam esse tipo de doença. A queixa clínica mais prevalente foi a dor muscular na região lombar (65\%) seguida de dores na coluna vertebral (10\%). A tendinite $(60 \%)$, as varizes $(40 \%)$ e a presbiopia $(40 \%)$ foram as doenças mais prevalentes que segundo os CDs entrevistados, foram ocasionadas pela prática profissional. Por conseguinte, a maioria dos CDs que trabalha no serviço público de saúde de Campina Grande já sofreu acidente perfurocortante durante o exercício da profissão e já teve ou tem alguma doença proveniente da prática profissional.
\end{abstract}

\title{
PalaVras-chaVe
}

Riscos ocupacionais; transtornos traumáticos cumulativos; odontologia.

\section{References}

1. Brasil. Ministério da Saúde. Diagnóstico, tratamento, reabilitação, prevenção e fisiologia da LER/DORT. Brasília; 2005.

2. Lelis RT, Presta AA, Garbin AJI, Garbin CAS. Verificação das queixas de saúde dos graduandos do $4^{\circ}$ ano da Faculdade de Odontologia de Araçatuba. Rev Fac Odontol Anápolis. 2004;6(2):102-5.

3. Presta AA, Garbin CAS, Garbin AJI, Saliba O. Avaliação da ocorrência de doenças e acidentes ocupacionais entre acadêmicos de odontologia. Rev Fac Odontol Passo Fundo. 2004;9(1):113-7.

4. Diaz.Caballero AJ, Gómez.Palencia IP, Díaz.Cárdenas S. Ergonomic factors that cause the presence of pain muscle in students of dentistry Med Oral Patol Oral Cir Bucal. 2010 Nov 1;15(6):906-11.

5. Casarin CAS, Caria PHF. Comportamento muscular durante diferentes práticas odontológicas. Cienc Odontol Bras. 2008;11(2):64-70.

6. Alpino G. Má postura e esforços repetitivos levam dentistas a mudar rotina de trabalho. Revista APCD. 2002;8(41):8-9.

7. Regis Filho, Michels G, Sell I. Lesões por esforços repetitivos/ distúrbios osteomusculares relacionados ao trabalho em cirurgiões-dentistas. Rev Bras Epidemiol [periódico na
Internet]. 2006 [acesso em 2007 julh 14]; 9(3): [telas]. Disponível em: <http://www.scielo.br/pdf/rbeip/v9n3/08.pdf >

8. Babaji P, Samadi F, Jaiswal JN, Bansal A. Occupational hazards among dentists: a review of literature. Jo Int Dental Medic Res. 2011;4(2):87-93.

9. Garbin AJI, Presta AA, Garbin CAS. Ocurrencia de accidentes ocupacionales y conducta en la práctica odontológica. Revista Cubana de Salud y Trabajo. 2006;7(1-2):29-33.

10. Blanck GLV, Garcia PL. Prevalência de exposições ocupacionais de cirurgiões-dentistas e auxiliares de consultório dentário a material biológico. Cad. Saúde Pública. [periódico na Internet]. 2006 [acesso em 2007 julh 14]; 22(1): [telas]. Disponível em: <http://www.scielo.br/scielo.php?Script=sci_art tex $+\&$ pid $=$ S0102311 x2006000100011>.

11. Rosa OPS, Lorenzo JL, Godoy SL. Controle de infecções cruzadas em odontologia. In: Lorenzo JL. Microbiologia para o estudante de Odontologia. São Paulo: Atheneu; 2004.

12. Cruz ALC, Silveira ADS. Importância da ergonomia e sua influência sobre as doenças ocupacionais da prática odontológica. Robrac. 2005;14(37):26-30.

13. Al Wassan KA et. al. Back \& Neck problems among dentists and dental auxiliaries. J Contemp Dent Pract 2001;3(2):017030 . 
14. Leggat PA, Kedjarune U, Smith DR. Occupational health problem in modern dentistry: A review. Industrial Health. 2007;45,11-21.

15. Santos Filho SB, Barreto SM. Atividade ocupacional e prevalência de dor osteomuscular em cirurgiões-dentistas de Belo Horizonte, Minas Gerais, Brasil: contribuição ao debate sobre os distúrbios osteomusculares relacionados ao trabalho. Cad. Saúde Pública. 2001;17(1):181-93.

16. Gonçalves CGO,Lacerda ABM, Ribas A, Oliva FC, Almeida SB, Marques JM. Exposição ocupacional ao ruído em odontólogos do Paraná: percepções e efeitos auditivos Rev Odontol UNESP. 2009;38(4):235-43.
Received: 02/01/2012

Accepted: 16/05/2012

Corresponding author: Maria Suênia Pereira da Silva Rua Olímpio Ponciano de Araújo, 53, Centro Queimadas- PB- CEP: 58475-000 marysupereira@yahoo.com.br 